\title{
CK2 blockade causes MPNST cell apoptosis and promotes degradation of $\beta$-catenin
}

\author{
Jed J. Kendall ${ }^{1}$, Katherine E. Chaney ${ }^{1}$, Ami V. Patel ${ }^{1}$, Tilat A. Rizvi ${ }^{1}$, David \\ A. Largaespada ${ }^{2}$, Nancy Ratner ${ }^{1}$ \\ ${ }^{1}$ Division of Experimental Hematology and Cancer Biology, Cincinnati Children's Hospital, Department of Pediatrics, University \\ of Cincinnati, Cincinnati, OH 45229, USA \\ ${ }^{2}$ Department of Pediatrics, Masonic Cancer Center, University of Minnesota, Minneapolis, MN 55455, USA
}

Correspondence to: Nancy Ratner, email: Nancy.Ratner@cchmc.org

Keywords: MPNST, CK2, G2 arrest, NF1, $\beta$-catenin

Published: July 18, 2016

\section{ABSTRACT}

Malignant peripheral nerve sheath tumors (MPNSTs) are soft tissue sarcomas that are a major cause of mortality of Neurofibromatosis type 1 (NF1) patients. MPNST patients have few therapeutic options available and only complete surgical resection can be curative. MPNST formation and survival are dependent on activated $\beta$-catenin signaling. The goal of this study was to determine if inhibition of the CK2 enzyme can be therapeutically exploited in MPNSTs, given CK2's role in mainta ining oncogenic phenotypes including stabilization of $\beta$-catenin. We found that CK2a is over-expressed in MPNSTs and is critical for maintaining cell survival, as the CK2 inhibitor, CX-4945 (Silmitasertib), and shRNA targeting CK2a each significantly reduce MPNST cell viability. These effects were preceded by loss of critical signaling pathways in MPNSTs, including destabilization of $\beta$-catenin and TCF8. CX-4945 administration in vivo slowed tumor growth and extends survival time. We conclude that CK2 inhibition is a promising approach to blocking $\beta$-catenin in MPNST cells, although combinatorial therapies may be required for maximal efficacy.

\section{INTRODUCTION}

Half of MPNSTs arise in context of NF1 disease, typically within benign plexiform neurofibromas [1], while the other half arise sporadically with no obvious precursor lesion or disease [2, 3]. The lifetime risk for NF1 patients developing a MPNST is $8-13 \%$. The 5 -year survival rate for patients with a sporadic or NF1 derived MPNST is poor ( $42 \%$ and $21 \%$, respectively) [3]. Surgical resection is the standard treatment for MPNSTs, but is often ineffective due to high rates of local tumor recurrence, distant metastasis and/or the site of the lesion precluding complete resection. If resection is incomplete, the patient 5-year survival rate is usually not impacted by therapies such as radiation or chemotherapy $[4,5]$.

Studies suggest that MPNST tumorigenesis is initiated when cells of the Schwann lineage lose expression of the $N F 1$ gene which encodes neurofibromin, a RAS-GAP protein; loss of neurofibromin delays RASGTP hydrolysis [6-10]. Progression to malignancy is associated with additional mutations in the NF1 null cells within the Schwann lineage, most commonly biallelic loss of $C D K N 2 A[11,12]$; mutations in PTEN, p53, and RB pathway genes have also been observed. [13-15].

Therapeutic strides against MPNSTs have been made in the pre-clinical setting. Drugs targeting MEK, a downstream effector of RAS, slow MPNST growth in pre-clinical mouse models [16-18]. Aurora-A-Kinase inhibitors have also been shown to cause prolonged growth arrest in preclinical mouse models [19]. To date, no single agent has been shown to be curative in animal models or in the clinic. Combinations of agents are showing more promise [20-23], and trials are being initiated to test their efficacy.

Understanding fundamental and unique survival mechanisms of MPNSTs should enable new therapeutic approaches. $\beta$-catenin is believed to be a critical regulator of MPNST survival. Over-expression of $\beta$-catenin in immortalized human Schwann cell lines (iHSCs) causes features of malignant transformation, and knockdown of $\beta$-catenin decreases MPNST cell viability [24-26]. Therefore, it is believed that targeting $\beta$-catenin might be a useful therapeutic strategy in MPNST. Indeed, targeting $\beta$-catenin is an attractive potential therapy 
in many cancer types [27]. While $\beta$-catenin is largely cytoplasmic in normal Schwann cells. However, in both neurofibromas and MPNSTs $\beta$-catenin shows pronounced nuclear localization leading to transcriptional activation of target genes $[24,25,28]$. $\beta$-catenin is degraded by a complex involving GSK-3 $\beta$, AXIN1, APC, CK1 and others that dock to $\beta$-catenin [29-33]. Once docked to the destruction complex, $\beta$-catenin is phosphorylated by GSK$3 \beta$ and CK1. This phosphorylation serves as a marker for ubiquitination and ultimately, degradation by the proteasome [34-36]. Mutations in $\beta$-catenin destruction complex genes lead to various cancers due to abnormally high levels of stabilized $\beta$-catenin protein [37-40]. However, targeting components of the canonical $\beta$-catenin destruction complex has to date been unsuccessful. It may be that targeting $\beta$-catenin without causing toxicity will require finding targets unique to a cancer that do not directly impact the ubiquitous GSK-3 $\beta$ destruction complex.

Most cancers share hallmark characteristics including hyper-proliferation and evasion of Programmed cell death that are often governed by similar molecular mechanisms [41]. For example, Casein Kinase 2 (CK2) is a serine/threonine kinase that is a regulator of oncogenic processes in diverse cancers $[42,43]$. Some of the progrowth and survival pathways regulated by CK2 include WNT/ $\beta$-catenin, Erk, and AKT signaling [44-49]. CK2 promotes $\beta$-catenin signaling by phosphorylating $\beta$-catenin in the armadillo arm region, preventing docking with the GSK-3 $\beta$ destruction complex [44]. CK2 also negatively regulates growth inhibitory pathways involving PTEN [50, 47, 51], suppresses apoptosis [52-55], and phosphorylates caspase 9 preventing cleavage from caspase 8 and evading cell Programmed apoptosis [56]. CK2 exists as a holoenzyme containing $\alpha$ and $\beta$ subunits $[42,57]$. In cancer, CK2 $\alpha$ is often overexpressed $[58,59]$ creating the formation of catalytically active CK2 $\alpha$ dimers that are able to phosphorylate targets unrecognized by the CK $2 \alpha$ / CK2 $\beta$ holoenzyme [60]. A defining characteristic of CK2 $\alpha$ dimers is constitutive activity. There are no known negative feedback loops to inhibit CK2 signaling. This unrestrained activation of downstream targets may be a key facilitator of oncogenic processes.

A selective CK2 inhibitor, CX-4945, developed by Cylene pharmaceuticals, is currently in phase II clinical trials as an anti-tumor agent [61, 62]. Using CK2 inhibitors alone or in combination with other drugs that target overlapping oncogenic pathways may be a useful therapeutic strategy. CK2 also plays a role in DNA damage repair. Therefore, CX-4945 is currently being tested in combination with Gemcitibene and Cisplatin in non-resectable cholangiocarcinomas [63, 64, 54].

In this study, we demonstrate that CK2 $\alpha$ is overexpressed in MPNST and is an essential regulator of MPNST survival. We show that pharmacological or genetic inhibition of CK2 diminishes MPNST cell viability and that CX-4945 slows tumor growth in vivo, extending the survival of mice with MPNST xenografted tumors. The mechanism by which CK2 facilitates MPNST survival is multifactorial, as CK2 inhibition decreases $\beta$-catenin and TCF- 8 protein stability, causes cell cycle arrest, and induces apoptosis.

\section{RESULTS}

\section{CK2 is overexpressed in MPNSTs}

We measured CK $2 \alpha$ protein and CK2 $\alpha$ mRNA expression in MPNST cell lines. QPCR revealed higher CK2 $\alpha$ mRNA expression in MPNST cell lines (2 to 5 fold) fold as compared to control normal human Schwann cells (NHSCs) (Figure 1A). The CK2 $\alpha$ protein was also overexpressed in each MPNST cell line (Figure 1B). If $\mathrm{CK} 2 \alpha$ is important for MPNST survival, then overexpression of $\mathrm{CK} 2 \alpha$ should lead to abnormal phosphorylation patterns of CK2 substrates. Western blot analysis of MPNST cell lines versus NHSCs using an antiCK2 substrate antibody (which recognizes CK2 consensus target motif pS/pTDXE only when phosphorylated) shows that $\mathrm{CK} 2 \alpha$ overexpression correlates with increased phosphorylation of CK2 target proteins. We identified CK2 substrate phosphorylation bands unique to MPNSTs based on size observed on the western blot. The identity of these bands is unknown to date (Figure 1C). CK2 $\alpha$ expression was analyzed in multiple human MPNST tissue ( $n=6$ different patients) and nerve $(n=2)$ biopsies using immunohistochemistry (IHC). CK2 $\alpha$ immunoreactivity appeared increased in MPNSTs as compared to the normal nerve, but showed variability among the MPNST samples (Figure 1D-1I).

\section{CK2 inhibition induces cell death and cell cycle arrest in MPNSTs in vitro}

To test if MPNST cells depend on CK2 $\alpha$ for survival, MPNST cell lines were treated with two different CSNK2A1 shRNAs, each of which decreased expression of the CK2 $\alpha$ protein (Figure 2A). MPNST cell viability, as measured by MTS assay, was significantly reduced by the knockdown of $\mathrm{CK} 2 \alpha$ at $72 \mathrm{~h}$ post infection (Figure 2B, 2C). We confirmed the sh-CSNK2A1 knockdown results by the pharmacological inhibition of CK2. CX-4945 is an anti-tumor agent in phase II clinical trials that inhibits CK2 activity by competitively binding to the CK2 enzyme active site [65]. To determine the effective concentrations of CX-4945, MPNST and iHSC cell lines were treated with CX-4945 for $72 \mathrm{~h}$ and cell viability was measured through MTS absorbance. At approximately $6 \mu \mathrm{m}$ CX-4945 decreased NF1 derived MPNST cell line viability by $50 \%$. CX-4945 at $10 \mu \mathrm{m}$ had maximal effect on NF1 derived MPNST cell line survival, causing significant reduction of viability at 72 h. The 26T sporadic MPNST cell line was more resistant to CX-4945 than the NF1 derived MPNST cell lines. An 
immortalized human Schwann cell (iHSC) control cell line was significantly more resistant to CX-4945 treatments as compared to MPNST cell lines (Figure 2D, 2E). MPNST cell lines were treated with CX-4945 for $24 \mathrm{~h}$ and harvested for western blot analysis. The antibody against CK2 phosphorylated target motif pS/pTDXE showed that increasing concentrations of CX-4945 progressively decreased CK2 substrate phosphorylation (Figure 2F). CX-4945 treatment induced apoptosis as indicated by increased cleaved PARP (Figure 2F) and increased the percent of cells in the $\mathrm{G} 2 / \mathrm{M}$ phase of the cell cycle, an indicator of cell cycle of arrest (Figure $2 \mathrm{G}$ ).

\section{CK2 regulates $\beta$-catenin protein stability in MPNSTs in vitro}

CK2 activity can induce canonical WNT signaling pathway activation by phosphorylating $\beta$-catenin in its armadillo repeat region [44]. This phosphorylation prevents interaction with the GSK-3 $\beta$ destruction complex, allowing $\beta$-catenin to translocate to the nucleus and induce target gene transcription $[44,66]$. As $\beta$-catenin expression is important for MPNST growth and survival [24, 25], and CK2 is elevated in MPSNTs, we hypothesized that CK2 might regulate $\beta$-catenin protein stability. CX-4945 treatment reduced $\beta$-catenin protein levels by $10 \mathrm{~min}$. and caused profound reduction by $12 \mathrm{~h}$ (Figure 3A). MPNST treatment with CX-4945 did not affect CTNNB1 mRNA levels (data not shown). This data suggests that CK2 likely regulates $\beta$-catenin protein stability in MPNST cells through a protective phosphorylation of the armadillo repeat region. Loss of $\beta$-catenin decreased MPNST cell viability in previous studies $[24,25]$. To begin to test if stabilization of $\beta$-catenin protein could rescue the cytotoxic effects of CK2 inhibition, we treated MPNST cells with CX-4945 and GSK-3 $\beta$ inhibitors $\mathrm{LiCl}$ or CHIR92201. Treatment with GSK-3 $\beta$ inhibitors partially rescued the cytotoxicity of $\mathrm{CK} 2$ inhibition (Figure $3 \mathrm{~B}$ ), as $\beta$-catenin protein levels (Figure $3 \mathrm{C}$ ) and downstream target gene expression AXIN2, LEF1, and C-MYC were restored (Figure 3D). To determine if $\beta$-catenin knock down phenocopies the G2/M arrest or apoptosis caused by CK2 inhibition, cells were treated with sh-CTNNB1 for $72 \mathrm{~h}$ and subjected to propidium iodide flow or western blot analysis. $\beta$-catenin knockdown phenocopied apoptosis as indicated by cleaved PARP (Figure 3E). However,
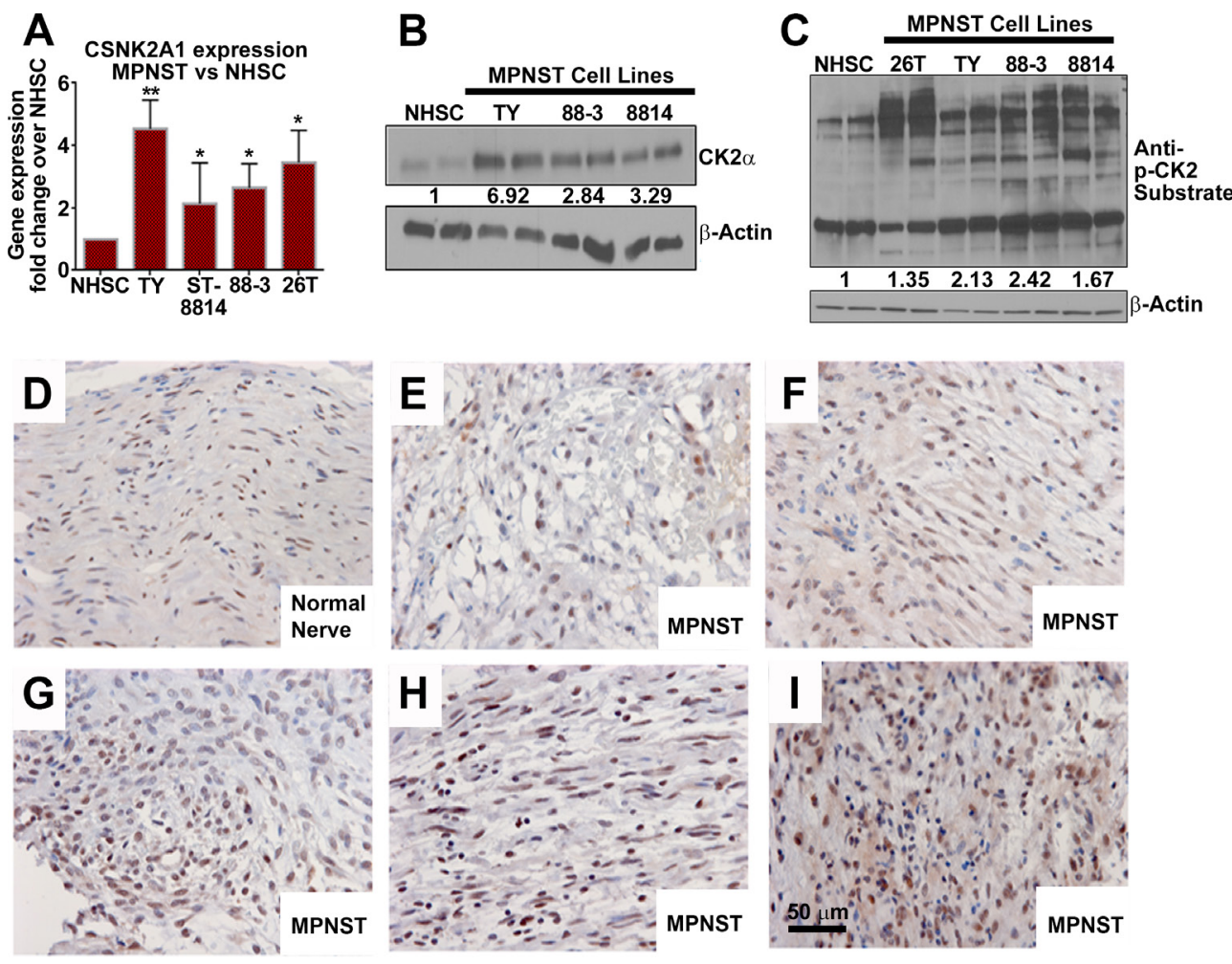

Figure 1: (A) Three designated MPNST cell lines show over-expression of CSNK2A1 mRNA vs NHSCs. (B) Western blot analysis shows that CK2 $\alpha$ protein is overexpressed in MPNST cell lines vs NHSCs. (C) Western blot analysis using an antibody that detects CK2 substrate phosphorylation reveals increased CK2 activity in MPNST cell lines. Some CK2 targets are phosphorylated in MPNSTs but not in NHSCs. (D-I) Expression of CK2 $\alpha$ shown by IHC in human nerve (D) and MPNST patient biopsy samples (E-I). Asterisks in A indicate statistically significant differences $\left(* p<0.05,{ }^{* *} p<0.01,{ }^{* * *} p<0.001\right)$. QPCR results are shown as the mean \pm standard deviation (S.D.) of three independent biological replicates, each in triplicate. Western blots are representative of at least 3 independent experiments. 
shCTNNB1 did not phenocopy CK2 mediated changes in the cell cycle profile (Figure 3F) suggesting that CK2 regulates additional mechanisms of cell survival.

\section{CK2 regulates survival factor TCF8 in MPSNTs in vitro}

To investigate mechanisms of survival regulated by $\mathrm{CK} 2$ that are independent of $\beta$-catenin we overlapped lists of known and predicted CK2 targets to genes overexpressed in MPNSTs, resulting in three potential targets: SIX1, TWIST1, and TCF8 [67, 68]. Of the potential three targets only TCF 8 decreased in response to CK2 inhibition (Figure 4A). Over-expression of the CK2 $\alpha$ subunit has been shown to drive over-expression of TCF8 in breast cancer and TCF8 contains potential CK2 phosphorylation sites [68-70]. To test if TCF8 is involved in MPNST survival we treated MPNSTs with TCF8 specific shRNA. Treatment of MPNSTs with TCF8 shRNA significantly decreased cell viability but had little effect on iHSCs as measured by a MTS assay 3 days post infection (Figure 4B). We demonstrate that the TCF8 shRNA knocks down TCF8 mRNA and protein by day 3 (Figure 4C, 4D). MPNSTs treated with shTCF8 undergo apoptosis as demonstrated by cleaved PARP western blot analysis (Figure 4D). However, cell cycle progression was not perturbed in MPNSTs through shRNA knockdown of TCF8 (Figure 4E).

\section{CX-4945 slows tumor growth in vivo}

To test the effectiveness of CX-4945 in vivo, athymic nude mice were injected with 1.5 million MPNST (S462-TY) cells. Treatment began when
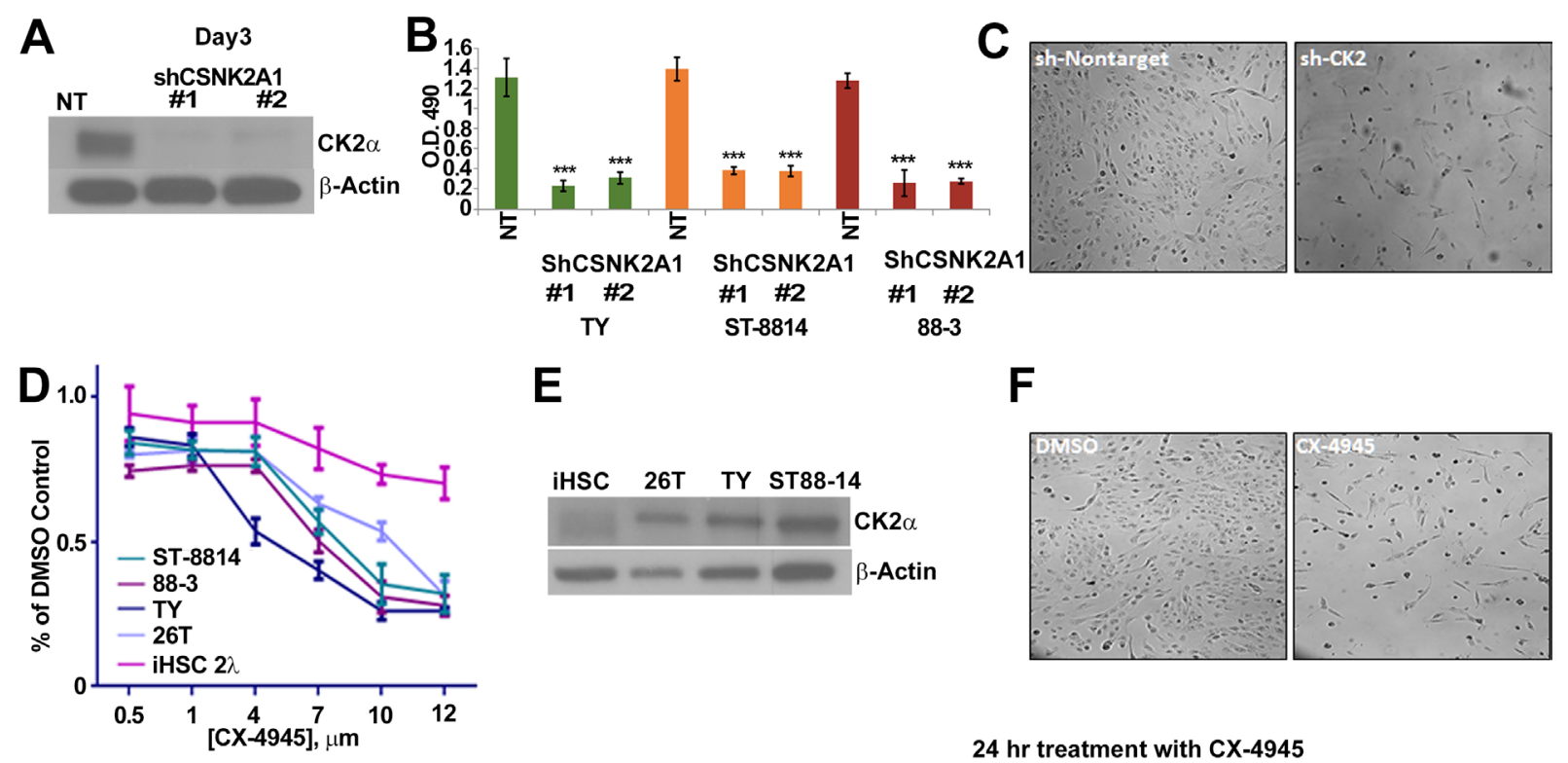

E

$\mathbf{F}$
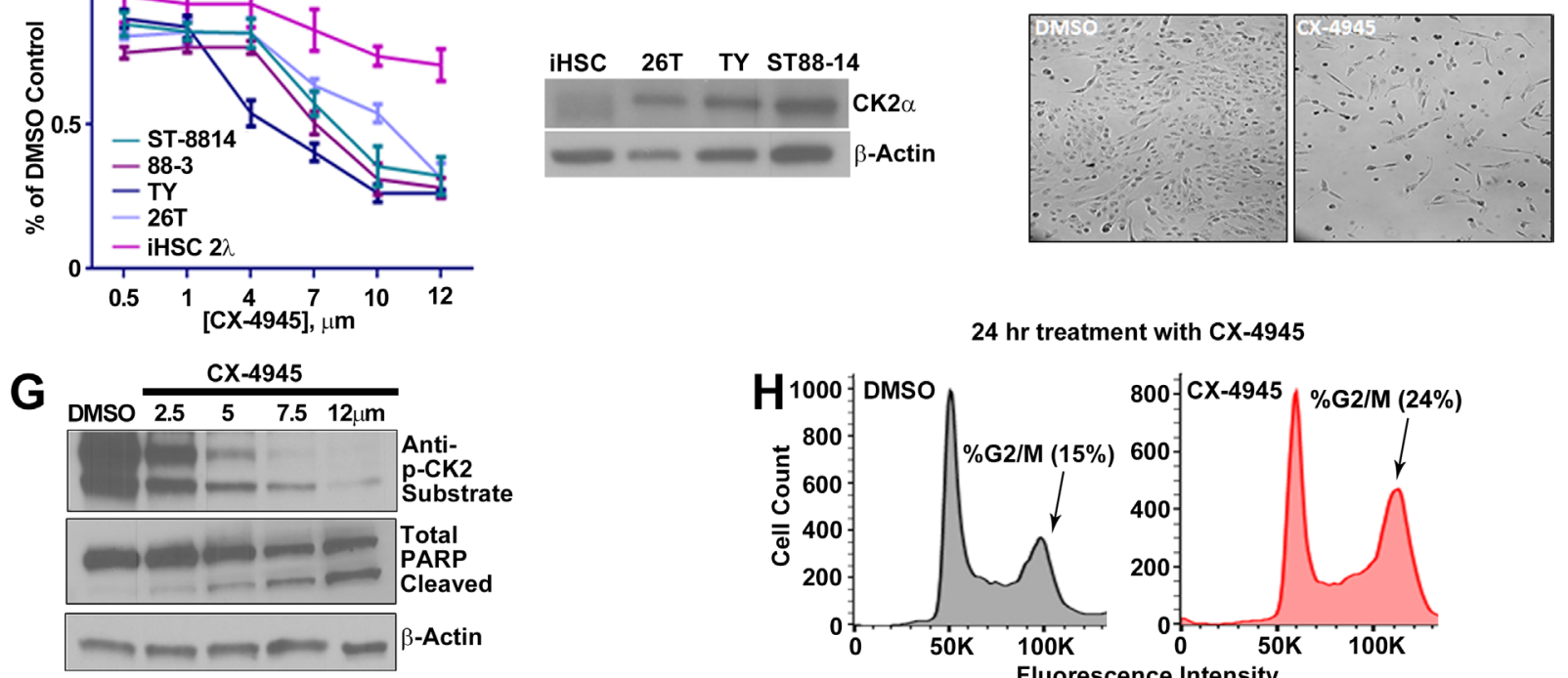

$24 \mathrm{hr}$ treatment with CX-4945

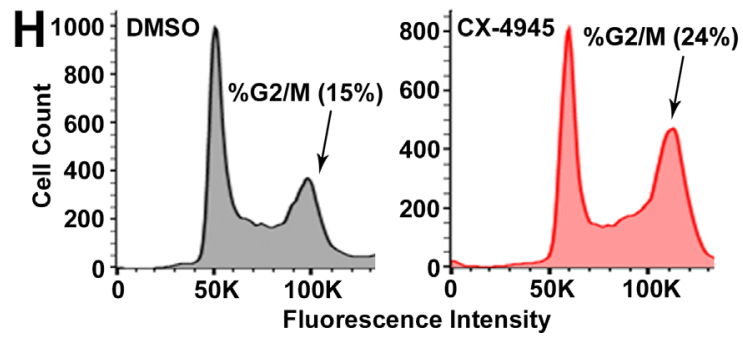

Figure 2: (A) MPNST (S462-TY) cells were treated with 2 unique shRNAs targeting CSNK2A1 for $72 \mathrm{~h}$, and western blot analysis confirmed a reduction of $\mathrm{CK} 2 \alpha$ protein. NT $=$ cells treated with a non-targeting shRNA control. (B) Three day CK2 $\alpha$ shRNA treatment had a cytotoxic effect on MPNST cell lines as measured by MTS; y-axis is O.D. reading at $490 \mathrm{~nm}$. (C) Phase contrast photomicrographs show S-462TY cells 3 days after NT or shCK2 $\alpha$ \#1. (D) Increasing concentrations of CX-4945 (72 h) decrease MPNST cell line growth. CX-4945 has less effect on control iHSC cells as measured by MTS; y-axis is O.D. reading at $490 \mathrm{~nm}$. (E) CK2 $\alpha$ is overexpressed in MPNST cell lines as compared to the iHSC control cell line. (F) Phase contrast shows that CX-4945 treatment depletes cell population at $24 \mathrm{~h}$ as compared to the DMSO control. (G) MPNST cell lines show a decrease in CK2 activity in response to escalating CX-4945 concentrations $(24 \mathrm{~h})$ as measured by a western blot analysis using anti-CK2 substrate, and to undergo apoptosis as indicated by increased cleaved PARP. H. CX-4945 causes MPNST cells (S462-TY) to increase the percent of cells in the G2/M phase of the cell cycle as indicated by flow analysis of propidium iodide stained cells (S.D. of DMSO $=1.8 \%$ and CX4945 = 3.8\%). Asterisks in B indicate differences after Student's $t$-test $(* p<0.05, * * p<0.01, * * * p<0.001)$. CX-4945 cell viability assay, MTS, and qPCR results are the mean of three independent biological replicates each in triplicate, \pm S.D. 
xenografts grew to an average of $250 \mathrm{MM} 3$. The study continued for 24 days, or until tumor burden reached $2500 \mathrm{~mm}^{3}$. At a dose of $75 \mathrm{mg} / \mathrm{kg}$ twice daily, CX4945 slowed MPNST tumor growth by approximately $50 \%$ through 15 days of treatment (Figure 5A). CX-4945 also significantly increased the survival of engrafted mice, with $66 \%$ of CX-4945 treated mice surviving through day 24 , while only $20 \%$ of the vehicle control treated mice survived 24 days (Figure 5B). Tumors were harvested $30 \mathrm{~min}$ and $3 \mathrm{~h}$ post CX-4945 treatment, and substrates were analyzed. CX-4945 treatment decreased phosphorylation of CK2 targets at $30 \mathrm{~min}$ and $3 \mathrm{~h}$. $\beta$-catenin and TCF8 protein levels were, however, only decreased at the $3 \mathrm{~h}$ time point (Figure 5C, 5F). CX4945 also decreased Ki67 expression indicating reduced proliferation (Figure 5D), but did not induce apoptotic cell death as measured by cleavage of Caspase 3 in MPNST xenografts (Figure 5E).

\section{MPNST treatment with CX-4945 in combination with PD0325901}

Hyper-activated RAS signaling is a hallmark of the NF1 syndrome. RAS activates downstream targets including MEK. Previous reports showed that CX-4945 can sensitize head and neck cancer to MEK inhibitors and MEK inhibition has been shown to slow MPNST tumor growth $[71,16]$. Therefore, we hypothesized that combination treatment with a MEK and CK2 inhibitor might be a more effective MPNST treatment than either single agent alone. To test this idea MPNSTs were treated with CX-4945, PD0325901, or PD0325901 and CX-4945 in vitro and cells were counted after $72 \mathrm{~h}$. Combination treatment decreased the MPNST cell population by $50-70 \%$ as compared to cells treated with either CX4945 or PD0325901 alone and the combination index (C.I. $=0.85)$ suggests that CX4945 with PD0325901 is moderately synergistic as defined by Compusyn (www. combosyn.com) (Figure 6A). The death marker cleaved PARP indicated that the combination of PD0325901 and CX-4945 caused a larger percentage of cells to enter apoptosis at $24 \mathrm{~h}$ as compared to equivalent doses of single agents (Figure 6B)

A xenograft study was performed to test the effectiveness of CX-4945 and PD0325901 as a combination treatment in vivo. However, the effect on tumor growth by the combination of CX-4945 with PD0325901 did not differ from mice treated with PD0325901 alone (Figure 6C). All mice treated with PD0325901 or PD0325901 with CX-
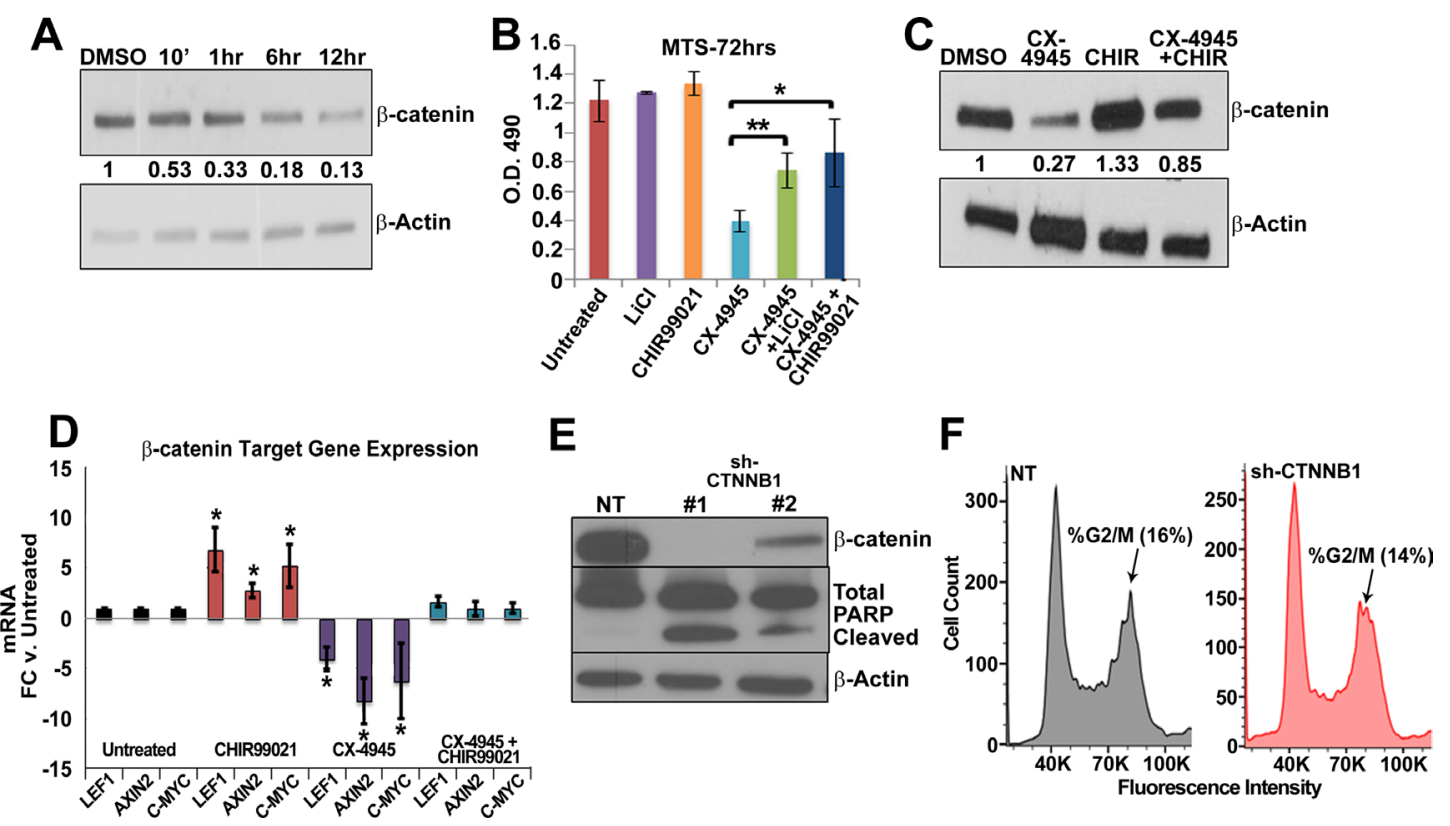

Figure 3: (A) Time course treatment of CX-4945 at $10 \mu \mathrm{m}$ decreases $\beta$ Catenin protein as early as 10 min in western blot analysis in MPNST (S462-TY) cells. (B) Partial rescue of CX-4945 MPNST cytotoxicity is achieved by inhibiting GSK-3 $\beta$ through CHIR99021 or $\mathrm{LiCl}$ as measured through MTS assay $72 \mathrm{~h}$. post treatment; y-axis is O.D. reading at $490 \mathrm{~nm}$. (C) Treatment with GSK-3 $\beta$ inhibitors restored $\beta$ Catenin protein in CX-4945 treated MPNST cells $(24 \mathrm{~h})$ as measured by western blot analysis. (D) Treatment with GSK-3 $\beta$ inhibitors restored $\beta$-Catenin target gene mRNA expression in CX-4945 treated MPNST cells $(24 \mathrm{~h})$ as measured by qPCR. (E) Western blot shows that shCTNNB1 induces apoptosis (cleaved PARP) in MPNST cells (S462-TY). (F) MPNST (S462-TY) cells treated with shRNA containing a non-targeting sequence or against $\beta$-Catenin and then stained with propidium iodide. Flow analysis of these samples reveals no significant difference in the cell cycle profile. (S.D. of NT $=1.6 \%$ and shCTNNB1 $=5.3 \%$ ). Western blot above the cell cycle analysis shows that the shRNA effectively targeted $\beta$-Catenin. Asterisks indicate statistically significant differences $(* p<0.05, * * p<0.01$, $*_{* *} p<0.001$ ); Student's $t$-test. MTS and qPCR results are the mean of three independent biological replicates each in triplicate \pm S.D. 
A

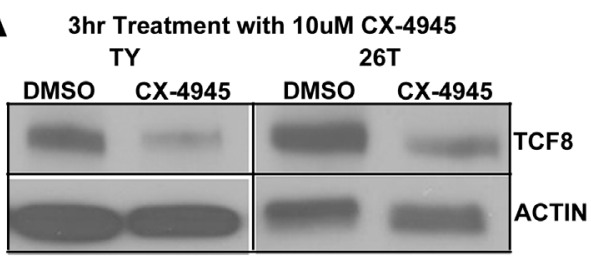

C

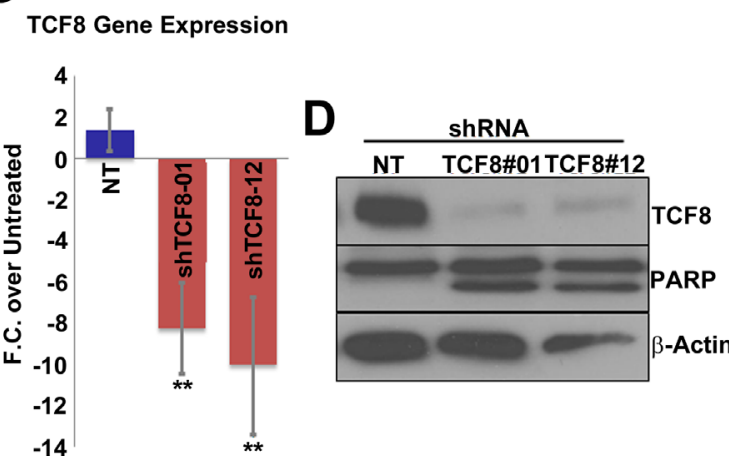

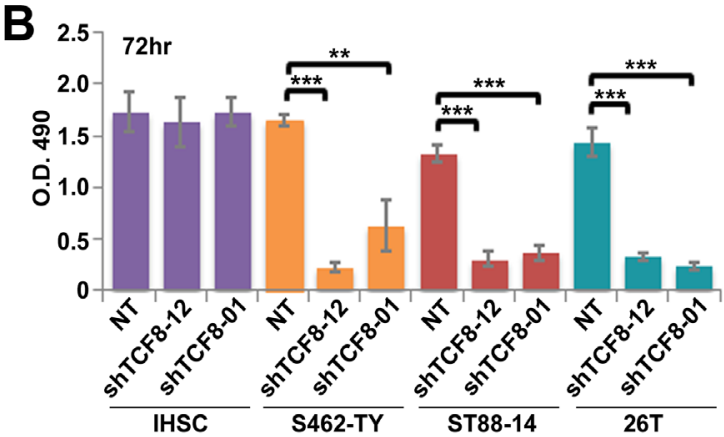

E

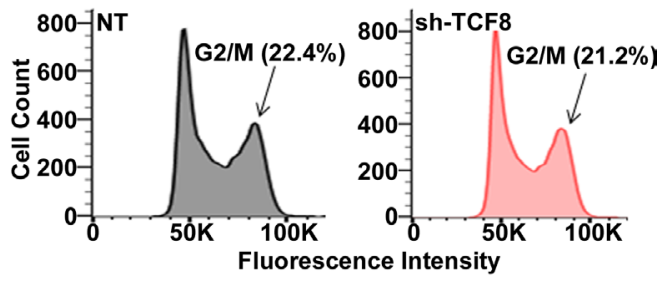

Figure 4: (A) CX-4945 treatment for $3 \mathrm{~h}$ decreases TCF8 protein expression in MPNST cell lines (S462-TY (TY) and 26T). (B) A $72 \mathrm{~h}$. treatment with TCF8 shRNA caused a significant decrease in MPNST cell viability in multiple MPNST cell lines, but not iHSC, in an MTS assay. NT = cells treated with non-targeting shRNA control. (C) TCF8 shRNA decreased TCF8 RNA expression in MPNSTs (S462-TY) $72 \mathrm{~h}$ post treatment. (D) TCF8 shRNA decreased TCF8 protein levels and induced apoptosis in MPNST cells (S462-TY) as indicated by increased levels of cleaved PARP. (E) TCF8 knockdown did not alter cell cycle progression (S.D. of G2/M phase: NT $=1.7 \%$ and shTCF8 $=1.3 \%$ ). Asterisks in B indicate statistically significant differences as for other figures. MTS, Flow, and qPCR results are the mean of three independent biological replicates in triplicate, \pm S.D.
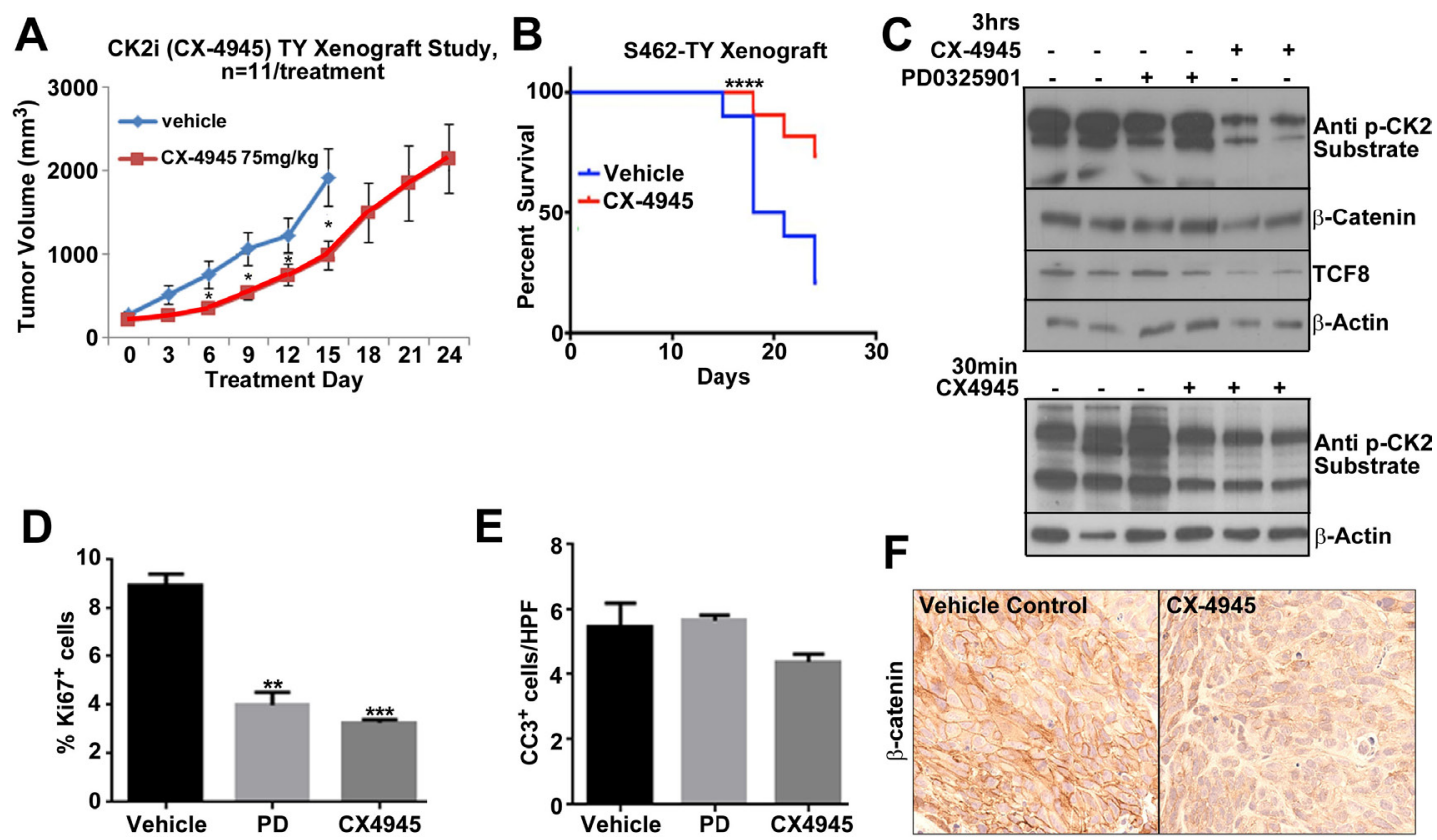

Figure 5: (A) MPNST xenograft growth was significantly reduced by CX-4945 $(p<0.05=*)$. (B) Survival of mice was significantly increased by CX-4945 treatment ( $p<.0001$ using a log-rank Mandel-Cox test). (C) Tumors were harvested from mice treated with CX4945 at $30 \mathrm{~min}$ or $3 \mathrm{~h}$ post last dose. Western blot analysis indicates that CX-4945 inhibited CK2 substrate phosphorylation. $\beta$-catenin and TCF8 protein levels were also reduced at the $3 \mathrm{~h}$ time point. Top, PD0325901 did not affect these targets. (D) Tissue sections from MPNST xenografts harvested $3 \mathrm{~h}$. after the last dose of CX-4945 show significantly decreased cell proliferation (Ki67+ cells). (E) Cell death (Cleaved Caspase 3) did not change in treatment groups (Cells per high-powered field; HPF). (F) $\beta$-catenin immunohistochemistry confirms that CX-4945 decreases $\beta$-catenin protein in MPNST xenografts. In E, F, effects of the MEK inhibitor are shown for comparison. Asterisks in D indicate statistically significant differences analyzed by ANOVA $\left({ }^{*} p<0.05, * * p<0.01,{ }^{* * *} p<0.001\right)$. 
4945 survived until day 24 (Figure 6D). Thus, while the in vitro results of combining CX-4945 and PD0325901 seemed promising, the in vivo combination treatment was no more effective than PD0325901 alone.

\section{DISCUSSION}

In this study we demonstrate that $\mathrm{CK} 2 \alpha$ is overexpressed in MPNST cells and that inhibition of CK2 through shRNA or with CX-4945 causes MPNST cells to arrest in the G2/M phase of the cell cycle and undergo apoptotic cell death. $\beta$-catenin plays a significant role in MPNST cell survival in vitro, and we find that
CK2 controls $\beta$-catenin protein stability in MPNST. Additionally, CK2 may regulate survival of MPNSTs through TCF8. CX-4945 inhibited tumor growth and increased survival in a MPNST xenograft model. It has been reported that there is minimal toxicity of CK2 inhibition in phase I clinical trials [72], making CX-4945, or other CK2 inhibitors, an appealing therapeutic approach for treating MPNSTs.

At least part of the effect of CX-4945 on MPNST cell survival is due to its reduction of $\beta$-catenin; partial rescue of CX-4945 cytotoxicity was achieved by re-expression of $\beta$-catenin using GSK-3 $\beta$ inhibitors, and knockdown of $\beta$-catenin phenocopies the apoptosis

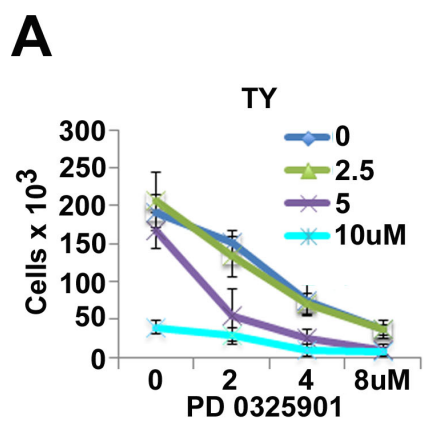

$72 \mathrm{hr}$ treatment CX-4945 + PD 0325901
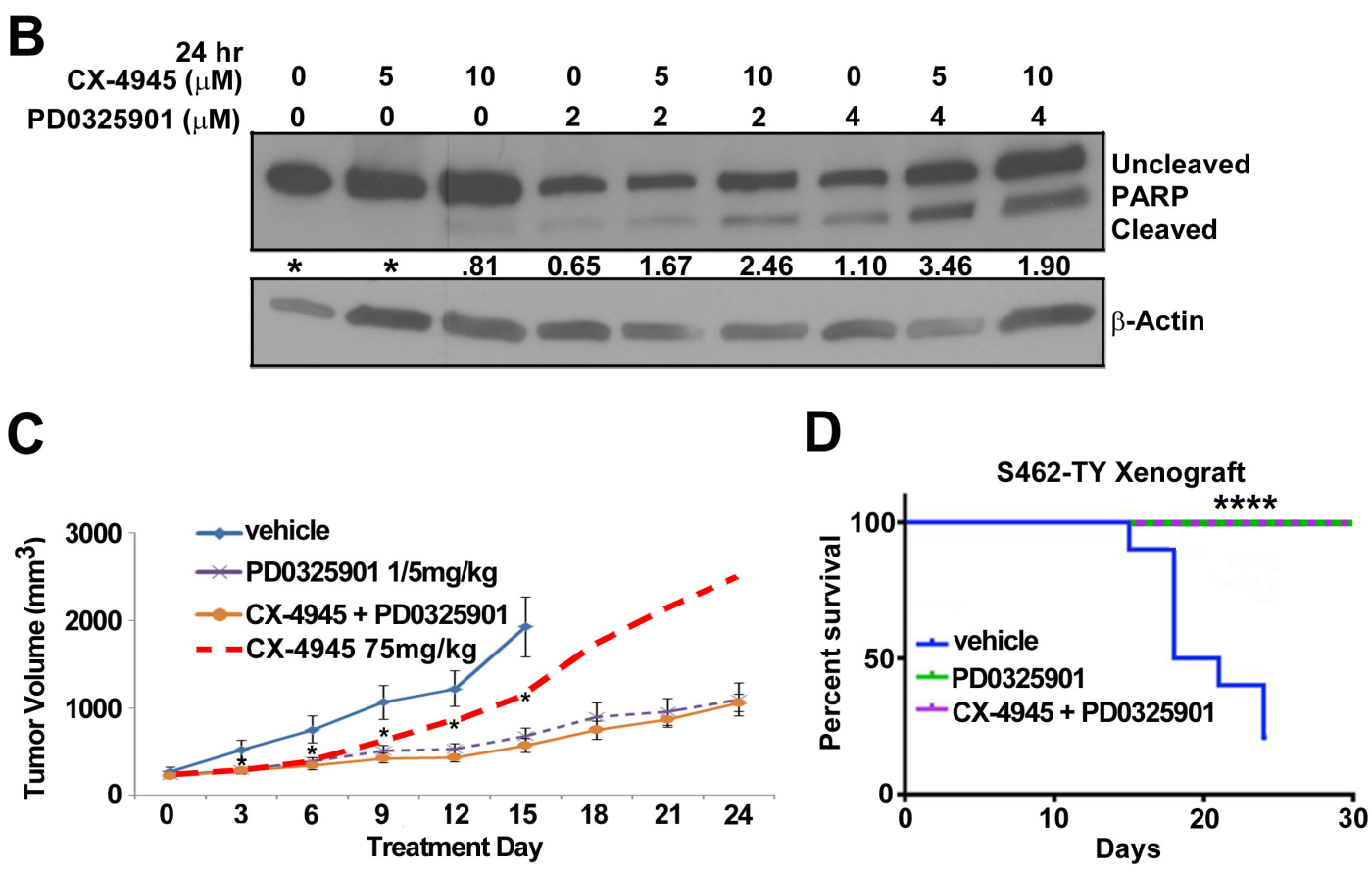

Figure 6: (A) $72 \mathrm{~h}$ combination treatment of CX-4945 and PD0325901 at concentrations 5 and $2 \mu \mathrm{m}$ respectively had an additive to synergistic effect on MPNST cell lines S462TY and ST88-14, but little effect on the sporadic 26T cell line. (B) MPNST cells treated for $24 \mathrm{~h}$ with CX-4945, PD0325901, or the combination revealed increasing PARP cleavage in combination treatments. (C) S462TY cells were grafted into nu/nu mice and segregated into vehicle, CX-4945, PD0325901, or CX-4945 + PD0325901 groups and were treated for 24 days. CX-4945 and PD0325901 both delayed tumor growth, however the CX-4945 + PD0325901 treatment did not slow tumor growth more than the PD0325901 treatment alone. CX-4945 tumor growth results represented by the dashed redline (data shown in Figure 5A). (D) Mice were removed from the survival curve at time of death or when the tumor volume reached $2500 \mathrm{~mm}^{3}$. All mice treated with PD0325901 or CX-4945 + PD0325901 survived until the end of the study at Day 30 ( $p<.0001$ using log-rank Mandel-Cox test). Asterisks in A ndicate statistically significant differences $\left(* p<0.05,{ }^{* *} p<0.01,{ }^{* *} p<0.001\right)$. In vitro MTS results are the mean of three biological replicates \pm S.D. 
caused by CK2 inhibition. However, shCTNNB1 did not phenocopy the modest G2/M arrest demonstrated by CK2 inhibition with CX-4945. These results compelled us to explore other pathways. We identified TCF8 as another potential MPNST survival factor. $T C F 8$ is consistently overexpressed in human MPNST cells and tumors (Miller et al., 2009), and CK2 inhibition caused a decrease in TCF8 protein. Knockdown of TCF8 using shRNA induced apoptosis in MPNSTs. Thus, CK2 regulates $\beta$-catenin and TCF8 stability to promote MPNST survival. This may be a general phenomenon, as CK $2 \alpha$ overexpression also resulted in TCF8 overexpression in breast cancer [73]. Precisely how CK2 facilitates cell cycle progression is unknown. Correlative data suggests that one CK2 substrate relevant to cell cycle regulation is SIX1 [74]. It is therefore of interest that several SIX transcripts (SIX1-4) show elevated expression in MPNST (Miller et al., 2010). Although SIX1 expression was not reduced by CK2 inhibition, the potential phosphorylation of SIX1 by CK2 may be important for MPNST cell viability.

Bian et al. (2015) reported that MEK inhibition sensitizes head and neck cancer cells to the cytotoxic effects of CK2 inhibition with CX-4945 [71]. We reproduced these results in MPNST cells in vitro, finding that MPNST cell survival was decreased by the combination of CX-4945 and PD0325901. Our xenograft studies confirmed that PD0325901 is effective at slowing MPNST growth, as previously shown using a dose of $10 \mathrm{mg} / \mathrm{kg}$ in another xenograft model [16]. The lower dose of $1.5 \mathrm{mg} / \mathrm{kg}$ used in this study is the mouse counterpart of the current recommended clinical dose. We found that $1.5 \mathrm{mg} / \mathrm{kg}$ PD0325901 dose significantly slowed tumor growth in a xenograft model and significantly down regulated MEK signaling. However, we failed to find any added benefit of the combination in the S462TY xenograft model at the doses tested. In mice, CX-4945 has a $5 \mathrm{~h}$ half-life and only $20 \%$ bioavailability (61), and reduced $\beta$-catenin protein partially and transiently. Most studies using CX-4945 in xenografts have dosed mice at $75 \mathrm{mg} / \mathrm{kg}$ b.i.d., as we did [71, 62, $63,65,75,61]$. Under these conditions, CX-4945 is under its IC50 for prolonged periods, even when dosing twice daily. In humans, however, CX-4945 has a half-life of $25 \mathrm{~h}$ and thus should be more effective than in mice. Reports from an adult phase I clinical trial concluded that CX-4945 4 times daily was more effective in maintaining CK2 inhibition in blood cells than a split dose of CX-4945 twice daily [76]. Further optimization of dose or schedule could also enhance the combinatorial effect with CX-4945. In addition, new generations of CK2 inhibitors might be used to test single agent activity and identify more effective combinations.

In conclusion, inhibiting CK2 activity decreased MPNST cell survival, which correlated with a reduction in $\beta$-catenin and TCF8 protein expression. Based on these findings, CK2 inhibition enables targeting of survival pathways in MPNST and supports further investigation of CX-4945 as a potential therapeutic.

\section{MATERIALS AND METHODS}

\section{Viral infection}

MPNST cells were seeded at $1.5 \times 10^{5}$ in 6 well plates and then transduced with lentivirus when wells became 10-20\% confluent. Target MOI for all infections was 10. Incubation of the virus was carried out at a minimal volume of $1 \mathrm{ml}$ with polybrene $(8 \mu \mathrm{g} / \mathrm{mL})$ (Sigma) overnight. Cells were then incubated in DMEM containing $10 \% \mathrm{FBS}$ and $1 \%$ penicillin/streptomycin with Puromycin $(2 \mathrm{ug} / \mathrm{ml})$. Lentiviruses encoding shRNA targeting CK2 (TRCN0000000607, TRCN0000320858), $\beta$-catenin (TRCN0000314921, TRCN0000314991), and TCF8 (TRCN0000017567, TRCN0000017564) were acquired from Sigma. Sigma non-targeting lentivirus (SHC016H) was used as a control.

\section{RNA preparation and real time quantitative RT-PCR (qPCR)}

The RNeasy kit (Qiagen) was used to isolate RNA. RNA was converted to cDNA using the ABI High capacity archive kit. Real time quantitative reverse transcriptase PCR (qPCR) was performed using Thermo scientific SYBR-green master mix. QPCR results were replicated with 3 different experimental samples and each qPCR was performed in triplicate. Expression of each gene was normalized to $\beta$-Actin. Human primers included: CSNK2A1 F-GCTGGGGGTAAGACCTTGTT and R - TTGTCTGTGTGAGCAGAGGG , $\beta$-ACTIN F-GTTGTCGACGACGAGCG and R-GCACAGAGCC TCGCCTT, AXIN2 F-CTGGTGCAAAGACATAGCCA and R-AGTGTGAGGTCCACGGAAAC, LEF1 FCACTGTAAGTGATGAGGGG and R-TGGATCTC TTTCTCCACCCA, C-MYC R-GACAAATGAACACAG CCCAA and L- GAGTCCATGGCCAGAAAACT, CTNNB1 F- ATTGTCCACGCTGGATTTTC and RTCGAGGACGGTCGGACT.

\section{Immunohistochemistry}

Paraffin sections were deparaffinized, hydrated and transferred to $0.1 \mathrm{M}$ citrate buffer ( $\mathrm{pH}$ 6.0) for antigen retrieval. Slides were boiled for 10 minutes in citrate buffer, cooled at room temperature for 30 minutes, rinsed in water twice and in PBS 3 times. Sections were quenched with 3\% hydrogen peroxide for 10 minutes, rinsed in PBS, and blocked in 10\% normal goat serum with $0.3 \%$ Triton-X-100. Sections were incubated overnight in primary antibody diluted in block; rabbit anti CK2 $\alpha$ on human MPNST and normal peripheral nerve (Abcam, ab76040 at a dilution of 1:200) and rabbit $\beta$-catenin 
(Cell Signaling, 8480 at a dilution of 1:200). Sections were then washed and incubated in goat anti rabbit biotinylated secondary antibodies (Vector, BA-1000) for 1 hour at room temperature, incubated in $\mathrm{ABC}$ (Vector, PK-6100) followed DAB (Vector, SK-4100) staining. Some sections were counterstained with Harris hemotoxylin. All microscopic images were acquired with Openlab software suites on a Zeiss Axiovert 200.

\section{Immunoblot}

Cell lysates were made with radioimmunoprecipitation assay buffer (RIPA) and western blotting was performed. Membranes were probed with antibodies for CK2 $\alpha$ 1:5000 (Cell Signaling, 2656), phosphorylated CK2 substrate 1:10,000 (Cell Signaling, 8738), PARP 1:5000 (Cell Signaling, 9542), $\beta$-catenin 1:10,000 (Cell Signaling, 9562), HRP conjugated $\beta$-Actin 1:50,000 (Cell Signaling, 5125), or TCF8 (Cell Signaling, 3396). Horseradish peroxidaseconjugated secondary antibodies (Jackson Labs) were incubated for $1 \mathrm{~h}$ at room temperature. Blot development was performed with ECL Plus developing system (Amersham Biosciences).

\section{Cell viability assays}

MPNST and iHSC cell lines (500 cells/well) were seeded in triplicate in 96-well plates. Cells were selected in Puro for $48 \mathrm{~h}$ and absorbance was read day 3 post-infection of CK2, TCF8, or $\beta$-catenin shRNA or day 3-post treatment with CX-4945. Absorbance reagent CellTiter $96^{\circledR}$ Aqueous One Solution Cell Proliferation Assay (Promega) was used. Combination drug studies using CX-4945 and PD0325901 were completed after a $72 \mathrm{~h}$ treatment time and cells were quantified with Biorad TC20 automated cell counter. Combination index was calculated using ComboSyn developed by Tin-Chao Chou.

\section{Cell cycle analysis}

Approximately 200,000 MPNST cells were seeded in a six well plate and then treated with CX-4945, DMSO, or shRNAs for $24 \mathrm{~h}$. Cells were harvested and fixed in methanol at $-20^{\circ} \mathrm{C}$ for 30 minutes to overnight and then washed in PBS before being stained with propidium iodide at $50 \mathrm{ug} / \mathrm{ml}$ (Sigma). A FACSCantos was used for Flow and data was analyzed using FlowJo software.

\section{Mouse xenograft}

$1.5 \times 10^{6}$ MPNST S462-TY cells suspended in Matrigel (BD) were injected subcutaneously into 6 to 8-week-old female athymic nude (nu/nu) mice (Harlan). Treatment of tumors began when the average tumor size was $250 \mathrm{~mm}^{3}$. CX-4945 sodium salt (Medchem Express, HY-50855B) was dissolved in $25 \mathrm{mM}$ sodium phosphate buffer $(\mathrm{pH}=4.3)$ (Sigma, 79629) and mice were treated twice daily at a dose of $75 \mathrm{mg} / \mathrm{kg}$ (71). PD0325901 was dissolved in $0.5 \%$ methylcellulose $/ 0.2 \%$ tween 80 in water and administered once a day at a dose of $1.5 \mathrm{mg} / \mathrm{kg}$ by oral gavage. Tumor volumes were measured every 3 days.

\section{Cell lines}

The ST88-14, S462TY, and 88-3 MPNST cell lines derived from patients with NF1 mutations. The STS26T MPNST cell line is derived from a sporadic MPNST with two WT NF1 alleles. The immortalized human Schwann cell line (iHSC) is derived from normal human sciatic nerve. The iHSCs contain no mutations in the NF1 alleles and was immortalized through expression of hTERT and CDK4 ${ }^{\mathrm{R} 24 \mathrm{C}}$ (Dr. Margaret Wallace, manuscript in preparation). All MPNST cell lines and iHSCs were cultured in Dulbecco's Modified Eagle Medium (DMEM) containing 10\% FBS and 1\% penicillin/streptomycin (Fisher). Normal human Schwann cells (NHSCs) were obtained from autopsy specimens and maintained as described [77].

\section{ACKNOWLEDGMENTS}

We thank Shyra J. Miller for editing this paper and Margart Wallace (U. Florida) for the iHSC cell line.

\section{CONFLICTS OF INTEREST}

The authors have no conflicts of interest to disclose.

\section{FUNDING}

This work was supported by grants from the National Institutes of Health 1R21NS084885-01A1 (NR and TPC), R01NS086219 (NR and DAL), and NS28840 (NR). The Cincinnati Children's Hospital Research Foundation, Flow Cytometry, Pathology, and Viral Vector Cores provided partial support for these studies (NIH P30 DK,090971055).

\section{REFERENCES}

1. Tucker T, Wolkenstein P, Revuz J, Zeller J, Friedman JM. Association between benign and malignant peripheral nerve sheath tumors in NF1. Neurology. 2005; 65:205-211. doi:10.1212/01.wnl.0000168830.79997.13.

2. De Raedt T, Brems H, Wolkenstein P, Vidaud D, Pilotti S, Perrone F, Mautner V, Frahm S, Sciot R, Legius E. Elevated risk for MPNST in NF1 microdeletion patients. Am J Hum Genet. 2003; 72:1288-1292. doi:10.1086/374821.

3. Evans DGR. Malignant peripheral nerve sheath tumours in neurofibromatosis 1. J Med Genet. 2002; 39:311-314. doi:10.1136/jmg.39.5.311. 
4. Kar M, Deo SVS, Shukla NK, Malik A, DattaGupta S, Mohanti BK, Thulkar S. Malignant peripheral nerve sheath tumors (MPNST) - Clinicopathological study and treatment outcome of twenty-four cases. World J Surg Oncol. 2006; 4:1-8. doi:10.1186/1477-7819-4-55.

5. Carli M, Ferrari A, MattkeA, Zanetti I, Casanova M, Bisogno G, Cecchetto G, Alaggio R, De Sio L, Koscielniak E, Koscielniak E, Sotti G, Treuner J. Pediatric malignant peripheral nerve sheath tumor: the Italian and German soft tissue sarcoma cooperative group. J Clin Oncol. 2005; 23:8422-8430. doi:10.1200/JCO.2005.01.4886.

6. Miller SJ. Large-Scale Molecular Comparison of Human Schwann Cells to Malignant Peripheral Nerve Sheath Tumor Cell Lines and Tissues. Cancer Res. 2006; 66:2584-2591. doi:10.1158/0008-5472.CAN-05-3330.

7. Vogel KS. Mouse Tumor Model for Neurofibromatosis Type 1 . Science (80-). 1999; 286:2176-2179. doi:10.1126/ science.286.5447.2176.

8. Cichowski K, Shih TS, Schmitt E, Santiago S, Reilly K, McLaughlin ME, Bronson RT, Jacks T. Mouse models of tumor development in neurofibromatosis type 1. Science. 1999; 286:2172-2176. http://www.ncbi.nlm.nih.gov/ pubmed/10591652. Accessed April 3, 2013.

9. Basu TN, Gutmann DH, Fletcher JA, Glover TW, Collins FS, Downward J. Aberrant regulation of ras proteins in malignant tumour cells from type 1 neurofibromatosis patients. Nature. 1992; 356:713-715. doi:10.1038/356713a0.

10. DeClue JE, Papageorge AG, Fletcher JA, Diehl SR, Ratner N, Vass WC, Lowy DR. Abnormal regulation of mammalian p21ras contributes to malignant tumor growth in von Recklinghausen (type 1) neurofibromatosis. Cell. 1992; 69:265-273. http://www.ncbi.nlm.nih.gov/ pubmed/1568246. Accessed March 9, 2016.

11. Nielsen GP, Stemmer-Rachamimov AO, Ino Y, Moller MB, Rosenberg AE, Louis DN. Malignant transformation of neurofibromas in neurofibromatosis 1 is associated with CDKN2A/p16 inactivation. Am J Pathol. 1999; 155: 1879-1884. doi:10.1016/S0002-9440(10)65507-1.

12. Beert E, Brems H, Daniëls B, De Wever I, Van Calenbergh F, Schoenaers J, Debiec-Rychter M, Gevaert O, De Raedt T, Van Den Bruel A, de Ravel T, Cichowski K, Kluwe L, et al. Atypical neurofibromas in neurofibromatosis type 1 are premalignant tumors. Genes Chromosomes Cancer. 2011; 50:1021-1032. doi:10.1002/gcc.20921.

13. Mawrin C, Kirches E, Boltze C, Dietzmann K, Roessner A, Schneider-Stock R. Immunohistochemical and molecular analysis of $\mathrm{p} 53, \mathrm{RB}$, and PTEN in malignant peripheral nerve sheath tumors. Virchows Arch. 2002; 440:610-615. doi:10.1007/s00428-001-0550-4.

14. Birindelli S, Perrone F, Oggionni M, Lavarino C, Pasini B, Vergani B, Ranzani GN, Pierotti MA, Pilotti S. Rb and TP53 Pathway Alterations in Sporadic and NF1-Related Malignant Peripheral Nerve Sheath Tumors. Lab Investig. 2001; 81:833-844. doi:10.1038/labinvest.3780293.
15. Perrone F, Da Riva L, Orsenigo M, Losa M, Jocollè G, Millefanti C, Pastore E, Gronchi A, Pierotti MA, Pilotti S. PDGFRA, PDGFRB, EGFR, and downstream signaling activation in malignant peripheral nerve sheath tumor. Neuro Oncol. 2009; 11:725-736. doi:10.1215/15228517-2009-003.

16. Jessen WJ, Miller SJ, Jousma E, Wu J, Rizvi TA, Brundage ME, Eaves D, Widemann B, Kim M-O, Dombi E, Sabo J, Hardiman Dudley A, Niwa-Kawakita M, et al. MEK inhibition exhibits efficacy in human and mouse neurofibromatosis tumors. J Clin Invest. 2013; 123:340-347. doi:10.1172/JCI60578.

17. Watson AL, Anderson LK, Greeley AD, Keng VW, Rahrmann EP, Halfond AL, Powell NM, Collins MH, Rizvi T, Moertel CL, Ratner N, Largaespada DA. Co-targeting the MAPK and PI3K/AKT/mTOR pathways in two genetically engineered mouse models of schwann cell tumors reduces tumor grade and multiplicity. Oncotarget. 2014; 5:15021514. doi:10.18632/oncotarget.1609.

18. Dodd RD, Mito JK, Eward WC, Chitalia R, Sachdeva M, Ma Y, Barretina J, Dodd L, Kirsch DG. NF1 deletion generates multiple subtypes of soft-tissue sarcoma that respond to MEK inhibition. Mol Cancer Ther. 2013; 12:1906-1917. doi:10.1158/1535-7163.MCT-13-0189.

19. PatelAV, Eaves D, Jessen WJ, Rizvi TA, Ecsedy JA, Qian MG, Aronow BJ, Perentesis JP, Serra E, Cripe TP, Miller SJ, Ratner N. Ras-driven transcriptome analysis identifies aurora kinase $\mathrm{A}$ as a potential malignant peripheral nerve sheath tumor therapeutic target. Clin Cancer Res. 2012; 18:5020-5030. doi:10.1158/1078-0432.ccr-12-1072.

20. Johannessen CM, Johnson BW, Williams SMG, Chan AW, Reczek EE, Lynch RC, Rioth MJ, McClatchey A, Ryeom S, Cichowski K. TORC1 Is Essential for NF1-Associated Malignancies. Curr Biol. 2008; 18:56-62. doi:10.1016/j. cub.2007.11.066.

21. Malone CF, Fromm JA, Maertens O, DeRaedt T, Ingraham R, Cichowski K. Defining key signaling nodes and therapeutic biomarkers in NF1-mutant cancers. Cancer Discov. 2014; 4:1062-1073. doi:10.1158/2159-8290.CD-14-0159.

22. De Raedt T, Walton Z, Yecies JL, Li D, Chen Y, Malone CF, Maertens O, Jeong SM, Bronson RT, Lebleu V, Kalluri R, Normant E, Haigis MC, et al. Exploiting Cancer Cell Vulnerabilities to Develop a Combination Therapy for Ras-Driven Tumors. Cancer Cell. 2011; 20:400-413. doi:10.1016/j.ccr.2011.08.014.

23. De Raedt T, Beert E, Pasmant E, Luscan A, Brems H, Ortonne N, Helin K, Hornick JL, Mautner V, KehrerSawatzki H, Clapp W, Bradner J, Vidaud M, et al. PRC2 loss amplifies Ras-driven transcription and confers sensitivity to BRD4-based therapies. Nature. 2014; 514:247-251. doi:10.1038/nature13561.

24. Watson AL, Rahrmann EP, Moriarity BS, Choi K, Conboy CB, Greeley AD, Halfond AL, Anderson LK, Wahl BR, Keng VW, Rizzardi AE, Forster CL, Collins MH, et al. Canonical Wnt/ -catenin Signaling Drives Human Schwann Cell Transformation, Progression, and Tumor Maintenance. 
Cancer Discov. 2013; 3:674-689. doi:10.1158/2159-8290. CD-13-0081.

25. Mo W, Chen J, Patel A, Zhang L, Chau V, Li Y, Cho W, Lim K, $\mathrm{Xu}$ J, Lazar AJ, Creighton CJ, Bolshakov S, McKay RM, et al. CXCR4/CXCL12 Mediate Autocrine Cell- Cycle Progression in NF1-Associated Malignant Peripheral Nerve Sheath Tumors. Cell. 2013; 152:1077-1090. doi:10.1016/j. cell.2013.01.053

26. Luscan A, Shackleford G, Masliah-Planchon J, Laurendeau I, Ortonne N, Varin J, Lallemand F, Leroy K, Dumaine V, Hivelin M, Borderie D, De Raedt T, Valeyrie-Allanore L, et al. The activation of the WNT signaling pathway is a Hallmark in neurofibromatosis type 1 tumorigenesis. Clin Cancer Res. 2014; 20:358-371. doi:10.1158/1078-0432. CCR-13-0780.

27. MacDonald BT, Tamai K, He X. Wnt/beta-catenin signaling: components, mechanisms, and diseases. Dev Cell. 2009; 17:9-26. doi:10.1016/j.devcel.2009.06.016.

28. Wu J, Keng V, Patmore DM, Kendall JJ, Patel AV, Jousma E, Jessen WJ, Choi K, Tschida BR, Silverstein KAT, Fan D, Schwartz EB, Fuchs JR, et al. Insertional Mutagenesis Identifies a STAT3/Arid1b/ $\beta$-catenin Pathway Driving Neurofibroma Initiation. Cell Rep. February 2016. doi:10.1016/j.celrep.2016.01.074.

29. Liu C, Li Y, Semenov M, Han C, Baeg GH, Tan Y, Zhang Z, Lin X, He X. Control of beta-catenin phosphorylation/ degradation by a dual-kinase mechanism. Cell. 2002; 108:837-847. http:/www.ncbi.nlm.nih.gov/pubmed/ 11955436. Accessed February 26, 2016.

30. Amit S, Hatzubai A, Birman Y, Andersen JS, BenShushan E, Mann M, Ben-Neriah Y, Alkalay I. Axinmediated CKI phosphorylation of beta-catenin at Ser 45: a molecular switch for the Wnt pathway. Genes Dev. 2002; 16:1066-1076. doi:10.1101/gad.230302.

31. Behrens J, Jerchow BA, Würtele M, Grimm J, Asbrand C, Wirtz R, Kühl M, Wedlich D, Birchmeier W. Functional interaction of an axin homolog, conductin, with betacatenin, APC, and GSK3beta. Science. 1998; 280:596-599. http://www.ncbi.nlm.nih.gov/pubmed/9554852. Accessed January 17, 2016.

32. Kishida S, Yamamoto H, Ikeda S, Kishida M, Sakamoto I, Koyama S, Kikuchi A. Axin, a negative regulator of the wnt signaling pathway, directly interacts with adenomatous polyposis coli and regulates the stabilization of beta-catenin. J Biol Chem. 1998; 273:10823-10826. http://www.ncbi.nlm. nih.gov/pubmed/9556553. Accessed February 26, 2016.

33. Spink KE, Polakis P, Weis WI. Structural basis of the Axinadenomatous polyposis coli interaction. EMBO J. 2000; 19:2270-2279. doi:10.1093/emboj/19.10.2270.

34. Hart M, Concordet JP, Lassot I, Albert I, del los Santos R, Durand H, Perret C, Rubinfeld B, Margottin F, Benarous R, Polakis P. The F-box protein beta-TrCP associates with phosphorylated beta-catenin and regulates its activity in the cell. Curr Biol. 1999; 9:207-210. http://www.ncbi.nlm.nih. gov/pubmed/10074433. Accessed February 26, 2016.
35. Orford K, Crockett C, Jensen JP, Weissman AM, Byers SW. Serine phosphorylation-regulated ubiquitination and degradation of beta-catenin. J Biol Chem. 1997; 272:24735-24738. http://www.ncbi.nlm.nih.gov/ pubmed/9312064. Accessed February 26, 2016.

36. Aberle H, Bauer A, Stappert J, Kispert A, Kemler R. beta-catenin is a target for the ubiquitin-proteasome pathway. EMBO J. 1997; 16:3797-3804. doi:10.1093/ emboj/16.13.3797.

37. Satoh S, Daigo Y, Furukawa Y, Kato T, Miwa N, Nishiwaki T, Kawasoe T, Ishiguro H, Fujita M, Tokino T, Sasaki Y, Imaoka $\mathrm{S}$, Murata $\mathrm{M}$, et al. AXIN1 mutations in hepatocellular carcinomas, and growth suppression in cancer cells by virus-mediated transfer of AXIN1. Nat Genet. 2000; 24:245-250. doi:10.1038/73448.

38. LiuW, Dong X, Mai M, Seelan RS, Taniguchi K, KrishnadathKK, Halling KC, Cunningham JM, Boardman LA, Qian C, Christensen E, Schmidt SS, Roche PC, et al. Mutations in AXIN2 cause colorectal cancer with defective mismatch repair by activating beta-catenin/TCF signalling. Nat Genet. 2000; 26:146-147. doi:10.1038/79859.

39. Peters JM, McKay RM, McKay JP, Graff JM. Casein kinase I transduces Wnt signals. Nature. 1999; 401:345-350. doi: $10.1038 / 43830$.

40. Munemitsu S, Albert I, Rubinfeld B, Polakis P. Deletion of an amino-terminal sequence beta-catenin in vivo and promotes hyperphosporylation of the adenomatous polyposis coli tumor suppressor protein. Mol Cell Biol. 1996; 16:4088-4094. http:/www.pubmedcentral.nih.gov/ articlerender.fcgi? artid $=231405 \&$ tool $=$ pmcentrez\&rendert ype=abstract. Accessed February 26, 2016.

41. Hanahan D, Weinberg RA. Hallmarks of cancer: the next generation. Cell. 2011; 144:646-674. doi:10.1016/j. cell.2011.02.013.

42. Guerra B, Issinger OG. Protein kinase CK2 and its role in cellular proliferation, development and pathology. Electrophoresis. 1999; 20:391-408. doi:10.1002/(SICI)15222683(19990201)20:2<391::AID-ELPS391>3.0.CO;2-N.

43. Ruzzene M, Pinna LA. Addiction to protein kinase CK2: a common denominator of diverse cancer cells? Biochim Biophys Acta. 2010; 1804:499-504. doi:10.1016/j. bbapap.2009.07.018.

44. Song DH, Dominguez I, Mizuno J, Kaut M, Mohr SC, Seldin DC. CK2 Phosphorylation of the Armadillo Repeat Region of -Catenin Potentiates Wnt Signaling. J Biol Chem. 2003; 278:24018-24025. doi:10.1074/jbc.M212260200.

45. Song DH, Sussman DJ, Seldin DC. Endogenous Protein Kinase CK2 Participates in Wnt Signaling in Mammary Epithelial Cells. J Biol Chem. 2000; 275:23790-23797. doi:10.1074/jbc.M909107199.

46. Seldin DC, Landesman-Bollag E, Farago M, Currier N, Lou D, Dominguez I. CK2 as a positive regulator of Wnt signalling and tumourigenesis. Mol Cell Biochem. 2005; 274:63-67. doi:10.1007/s11010-005-3078-0. 
47. Shehata M, Schnabl S, Demirtas D, Hilgarth M, Hubmann R, Ponath E, Badrnya S, Lehner C, Hoelbl A, Duechler M, Gaiger A, Zielinski C, Schwarzmeier JD, et al. Reconstitution of PTEN activity by CK2 inhibitors and interference with the PI3-K/Akt cascade counteract the antiapoptotic effect of human stromal cells in chronic lymphocytic leukemia. Blood. 2010; 116:2513-2521. doi:10.1182/blood-2009-10-248054.

48. Chao CC, Ma YL, Lee EHY. Protein kinase CK2 impairs spatial memory formation through differential cross talk with PI-3 kinase signaling: activation of Akt and inactivation of SGK1. J Neurosci. 2007; 27:6243-6248. doi:10.1523/JNEUROSCI.1531-07.2007.

49. Schevzov G, Kee AJ, Wang B, Sequeira VB, Hook J, Coombes JD, Lucas CA, Stehn JR, Musgrove EA, Cretu A, Assoian R, Fath T, Hanoch T, et al. Regulation of cell proliferation by ERK and signal-dependent nuclear translocation of ERK is dependent on Tm5NM1-containing actin filaments. Mol Biol Cell. 2015; 26:2475-2490. doi:10.1091/mbc.E14-10-1453.

50. Barata JT. The impact of PTEN regulation by CK2 on PI3K-dependent signaling and leukemia cell survival. Adv Enzyme Regul. 2011; 51:37-49. doi:10.1016/j. advenzreg.2010.09.012.

51. Torres J, Pulido R. The tumor suppressor PTEN is phosphorylated by the protein kinase CK2 at its $\mathrm{C}$ terminus. Implications for PTEN stability to proteasome-mediated degradation. J Biol Chem. 2001; 276:993-998. doi:10.1074/ jbc.M009134200.

52. Manni S, Brancalion A, Tubi LQ, Colpo A, Pavan L, Cabrelle A, Ave E, Zaffino F, Di Maira G, Ruzzene M, Adami F, Zambello R, Pitari MR, et al. Protein kinase CK2 protects multiple myeloma cells from ER stress-induced apoptosis and from the cytotoxic effect of HSP90 inhibition through regulation of the unfolded protein response. Clin Cancer Res. 2012; 18:1888-1900. doi:10.1158/1078-0432.CCR-11-1789.

53. Dixit D, Sharma V, Ghosh S, Mehta VS, Sen E. Inhibition of Casein kinase-2 induces p53-dependent cell cycle arrest and sensitizes glioblastoma cells to tumor necrosis factor (TNF $\alpha$ )-induced apoptosis through SIRT1 inhibition. Cell Death Dis. 2012; 3:e271. doi:10.1038/cddis.2012.10.

54. Kim GS, Jung JE, Narasimhan P, Sakata H, Yoshioka H, Song YS, Okami N, Chan PH. Release of mitochondrial apoptogenic factors and cell death are mediated by CK2 and NADPH oxidase. J Cereb Blood Flow Metab. 2011; 32:720-730. doi:10.1038/jcbfm.2011.176.

55. Hanif IM, Pervaiz S. Repressing the activity of protein kinase CK2 releases the brakes on mitochondria-mediated apoptosis in cancer cells. Curr Drug Targets. 2011; 12: 902-908. http://www.ncbi.nlm.nih.gov/pubmed/21269261. Accessed January 11, 2016.

56. Turowec JP, Duncan JS, Gloor GB, Litchfield DW. Regulation of caspase pathways by protein kinase CK2: identification of proteins with overlapping CK2 and caspase consensus motifs. Mol Cell Biochem. 2011; 356:159-167. doi:10.1007/s11010-011-0972-5.
57. Allende JE, Allende CC. Protein kinases. 4. Protein kinase CK2: an enzyme with multiple substrates and a puzzling regulation. FASEB J. 1995; 9:313-323. http:/www.ncbi. nlm.nih.gov/pubmed/7896000. Accessed March 10, 2016.

58. Kim JS, Eom JI, Cheong J-W, Choi AJ, Lee JK, Yang WI, Min YH. Protein kinase CK2 $\alpha$ lpha as an unfavorable prognostic marker and novel therapeutic target in acute myeloid leukemia. Clin Cancer Res. 2007; 13:1019-1028. doi:10.1158/1078-0432.CCR-06-1602.

59. Laramas M, Pasquier D, Filhol O, Ringeisen F, Descotes J-L, Cochet C. Nuclear localization of protein kinase CK2 catalytic subunit (CK2 $\alpha$ lpha) is associated with poor prognostic factors in human prostate cancer. Eur J Cancer. 2007; 43:928-934. doi:10.1016/j.ejca.2006.11.021.

60. Filhol O, Giacosa S, Wallez Y, Cochet C. Protein kinase $\mathrm{CK} 2$ in breast cancer: the CK2 $\beta$ regulatory subunit takes center stage in epithelial plasticity. Cell Mol Life Sci. 2015; 72:3305-3322. doi:10.1007/s00018-015-1929-8.

61. Pierre F, Chua PC, O’Brien SE, Siddiqui-Jain A, Bourbon P, Haddach M, Michaux J, Nagasawa J, Schwaebe MK, Stefan E, Vialettes A, Whitten JP, Chen TK, et al. Discovery and SAR of 5-(3-chlorophenylamino)benzo[c] $[2,6]$ naphthyridine-8-carboxylic acid (CX-4945), the first clinical stage inhibitor of protein kinase CK2 for the treatment of cancer. J Med Chem. 2011; 54:635-654. doi:10.1021/jm101251q.

62. Siddiqui-Jain A, Drygin D, Streiner N, Chua P, Pierre F, O'Brien SE, Bliesath J, Omori M, Huser N, Ho C, Proffitt C, Schwaebe MK, Ryckman DM, et al. CX-4945, an Orally Bioavailable Selective Inhibitor of Protein Kinase CK2, Inhibits Prosurvival and Angiogenic Signaling and Exhibits Antitumor Efficacy. Cancer Res. 2010; 70:10288-10298. doi:10.1158/0008-5472.CAN-10-1893.

63. Siddiqui-Jain A, Bliesath J, Macalino D, Omori M, Huser N, StreinerN, Ho CB, Anderes K, ProffittC, O’Brien SE, Lim JKC, Von Hoff DD, Ryckman DM, et al. CK2 inhibitor CX-4945 suppresses DNA repair response triggered by DNA-targeted anticancer drugs and augments efficacy: mechanistic rationale for drug combination therapy. Mol Cancer Ther. 2012; 11:994-1005. doi:10.1158/1535-7163.MCT-11-0613.

64. Ghavidel A, Schultz MC. TATA binding proteinassociated CK2 transduces DNA damage signals to the RNA polymerase III transcriptional machinery. Cell. 2001; 106:575-584. http:/www.ncbi.nlm.nih.gov/ pubmed/11551505. Accessed December 17, 2015.

65. Pierre F, Chua PC, O'Brien SE, Siddiqui-Jain A, Bourbon P, Haddach M, Michaux J, Nagasawa J, Schwaebe MK, Stefan E, Vialettes A, Whitten JP, Chen TK, et al. Pre-clinical characterization of CX-4945, a potent and selective small molecule inhibitor of CK2 for the treatment of cancer. Mol Cell Biochem. 2011; 356:37-43. doi:10.1007/s11010-0110956-5.

66. Gao Y, Wang $\mathrm{H}-\mathrm{y}$. Casein Kinase 2 Is Activated and Essential for Wnt/beta-Catenin Signaling. J Biol Chem. 2006; 281:18394-18400. doi:10.1074/jbc.M601112200. 
67. Miller SJ, Jessen WJ, Mehta T, Hardiman A, Sites E, Kaiser S, Jegga AG, Li H, Upadhyaya M, Giovannini M, Muir D, Wallace MR, Lopez E, et al. Integrative genomic analyses of neurofibromatosis tumours identify SOX9 as a biomarker and survival gene. EMBO Mol Med. 2009; 1:236-248. doi:10.1002/emmm.200900027.

68. Bian Y, Ye M, Wang C, Cheng K, Song C, Dong M, Pan Y, Qin H, Zou H. Global screening of CK2 kinase substrates by an integrated phosphoproteomics workflow. Sci Rep. 2013; 3:3460. doi:10.1038/srep03460.

69. Deshiere A, Duchemin-Pelletier E, Spreux E, Ciais D, Combes F, Vandenbrouck Y, Couté Y, Mikaelian I, Giusiano S, Charpin C, Cochet C, Filhol O. Unbalanced expression of CK2 kinase subunits is sufficient to drive epithelial-tomesenchymal transition by Snail1 induction. Oncogene. 2013; 32:1373-1383. doi:10.1038/onc.2012.165.

70. Chung D-WD, Frausto RF, Ann LB, Jang MS, Aldave AJ. Functional impact of ZEB1 mutations associated with posterior polymorphous and Fuchs' endothelial corneal dystrophies. Invest Ophthalmol Vis Sci. 2014; 55:6159-6166. doi:10.1167/iovs.14-15247.

71. Bian Y, Han J, Kannabiran V, Mohan S, Cheng H, Friedman J, Zhang L, VanWaes C, Chen Z. MEK inhibitor PD-0325901 overcomes resistance to CK2 inhibitor CX-4945 and exhibits anti-tumor activity in head and neck cancer. Int J Biol Sci. 2015; 11:411-422. doi:10.7150/ijbs.10745.

72. Marschke RF, Borad MJ, McFarland RW, Alvarez RH, Lim JK, Padgett CS, Von Hoff DD, O'Brien DWN SE. Findings from the phase I clinical trials of CX-4945, an orally available inhibitor of CK2. | 2011 ASCO Annual Meeting | Abstracts | Meeting Library. http://meetinglibrary.asco.org/ content/84525-102. Accessed March 10, 2016.

73. Jang MH, Kim HJ, Kim EJ, Chung YR, Park SY. Expression of epithelial-mesenchymal transition-related markers in triple-negative breast cancer: ZEB1 as a potential biomarker for poor clinical outcome. Hum Pathol. 2015; 46:1267-1274. doi:10.1016/j.humpath.2015.05.010.

74. Ford HL, Landesman-Bollag E, Dacwag CS, Stukenberg PT, Pardee AB, Seldin DC. Cell cycle-regulated phosphorylation of the human SIX1 homeodomain protein. J Biol Chem. 2000; 275:22245-22254. doi:10.1074/jbc.M002446200.

75. Zheng Y, McFarland BC, Drygin D, Yu H, Bellis SL, Kim H, Bredel M, Benveniste EN. Targeting protein kinase CK2 suppresses prosurvival signaling pathways and growth of glioblastoma. Clin Cancer Res. 2013; 19:6484-6494. doi:10.1158/1078-0432.CCR-13-0265.

76. 414 Clinical pharmacokinetics and pharmacodynamics of CX4945, a novel inhibitor of protein kinase CK2: Interim report from the phase 1 clinical trial | Donald Northfelt - Academia. edu. http://www.academia.edu/18731800/414_Clinical_ pharmacokinetics_and_pharmacodynamics_of_CX-4945_a novel_inhibitor_of_protein_kinase_CK2_Interim_report_ from_the_phase_1_clinical_trial. Accessed March 7, 2016.

77. Rosenbaum T, Rosenbaum C, Winner U, MüllerHW, LenardHG, Hanemann CO. Long-term culture and characterization of human neurofibroma-derived Schwann cells. J Neurosci Res. 2000; 61:524-532. http://www.ncbi.nlm.nih.gov/ pubmed/10956422. Accessed March 7, 2016. 